\title{
Otolith size and the vestibulo-ocular reflex of larvae of white seabass Atractoscion nobilis at high $\mathrm{pCO}_{2}$
}

\author{
Sara G. Shen ${ }^{1, *}$, Fangyi Chen ${ }^{2}$, David E. Schoppik ${ }^{3}$, David M. Checkley Jr. ${ }^{1}$ \\ ${ }^{1}$ Scripps Institution of Oceanography, University of California San Diego, La Jolla, CA 92093, USA \\ ${ }^{2}$ Department of Biology, South University of Science and Technology of China, Shenzhen, Guangdong 518055, PR China \\ ${ }^{3}$ Department of Physiology and Neuroscience, New York University School of Medicine, New York, NY 10016, USA
}

\begin{abstract}
We investigated vestibular function and otolith size (OS) in larvae of white seabass Atractoscion nobilis exposed to high partial pressure of $\mathrm{CO}_{2}\left(p \mathrm{CO}_{2}\right)$ The context for our study is the increasing concentration of $\mathrm{CO}_{2}$ in seawater that is causing ocean acidification (OA). The utricular otoliths are aragonitic structures in the inner ear of fish that act to detect orientation and acceleration. Stimulation of the utricular otoliths during head movement results in a behavioral response called the vestibulo-ocular reflex (VOR). The VOR is a compensatory eye rotation that serves to maintain a stable image during movement. VOR is characterized by gain (ratio of eye amplitude to head amplitude) and phase shift (temporal synchrony). We hypothesized that elevated $p \mathrm{CO}_{2}$ would increase OS and affect the VOR. We found that the sagittae and lapilli of young larvae reared at $2500 \mu$ atm $p \mathrm{CO}_{2}$ (treatment) were 14 to $20 \%$ and 37 to $39 \%$ larger in area, respectively, than those of larvae reared at $400 \mu \mathrm{atm} p \mathrm{CO}_{2}$ (control). The mean gain of treatment larvae $(0.39 \pm 0.05, \mathrm{n}=28)$ was not statistically different from that of control larvae $(0.30 \pm 0.03, \mathrm{n}$ $=20$ ), although there was a tendency for treatment larvae to have a larger gain. Phase shift was unchanged. Our lack of detection of a significant effect of elevated $p \mathrm{CO}_{2}$ on the VOR may be a result of the low turbulence conditions of the experiments, large natural variation in otolith size, calibration of the VOR or mechanism of acid-base regulation of white seabass larvae.
\end{abstract}

KEY WORDS: Ocean acidification $\cdot$ Fish larvae $\cdot$ Otolith $\cdot$ Vestibulo-ocular reflex $\cdot p \mathrm{CO}_{2}$

\section{INTRODUCTION}

Humans are disrupting the equilibrium of the ocean carbon cycle at a greater magnitude and rate than nature has achieved over the past 300 million years of Earth history (Hönisch et al. 2012). Ocean acidification $(\mathrm{OA})$ is the increase in surface seawater partial pressure of $\mathrm{CO}_{2}\left(p \mathrm{CO}_{2}\right)$ and decrease in $\mathrm{pH}$ and calcium carbonate saturation state $(\Omega)$ caused by the imbalance in the rates of addition to the ocean of carbon by the burning of fossil fuels and alkalinity by weathering (Doney et al. 2009, Hönisch et al. 2012). Humans have released $555 \mathrm{Pg}$ of carbon into the atmosphere through fossil fuel burning since the Industrial Revolution, increasing atmospheric $p \mathrm{CO}_{2}$ from 278 to $>400 \mathrm{ppm}$ today and decreasing $\mathrm{pH}$ by 0.10

${ }^{*}$ Corresponding author: sgshen@ucsd.edu units (Doney et al. 2009, IPCC 2013). Atmospheric $p \mathrm{CO}_{2}$ is projected to exceed $1000 \mathrm{ppm}$ by the end of the century and 1900 ppm by the year 2250 under the Intergovernmental Panel on Climate Change (IPCC) business-as-usual (Representative Concentration Pathway 8.5) scenario, further decreasing $\mathrm{pH}$ by 0.30 to 0.77 units (Caldeira \& Wickett 2003, IPCC 2013).

The effects of OA on marine fish are diverse (see review by Heuer \& Grosell 2014), variable and most severe during the early life-history stages (Rombough 1988, Tseng et al. 2013). The dynamics of these stages are critical in determining future population size and recruitment success (Houde 1997). Experiments show that elevated $p \mathrm{CO}_{2}$ can influence growth (Munday et al. 2009a, Baumann et al. 2012), condition (Franke \& Clemmesen 2011, Frommel et al.

() The authors 2016. Open Access under Creative Commons by Attribution Licence. Use, distribution and reproduction are unrestricted. Authors and original publication must be credited. 
2012) and mortality (Baumann et al. 2012, Chambers et al. 2014) of fish eggs and larvae. Altered auditory (Simpson et al. 2011), olfactory (Munday et al. 2009b, Devine et al. 2012) and visual (Forsgren et al. 2013, Chung et al. 2014) sensory abilities that have resulted in behavioral changes are thought to be the result of modifications to the $\gamma$-aminobutyric acid $\left(\mathrm{GABA}_{\mathrm{A}}\right)$ neurotransmitter receptor in the brain (Nilsson et al. 2012, Hamilton et al. 2014). Another widespread effect of elevated $p \mathrm{CO}_{2}$ is the increase in otolith size (OS) (Checkley et al. 2009, Munday et al. 2011, Bignami et al. 2013a, Réveillac et al. 2015).

Otoliths are aragonitic structures underlain by sensory hair cells located in the inner ear of fish, and play a vital role in the auditory and vestibular systems (Platt 1983, Popper et al. 2005). The vestibular system provides vertebrates with information about orientation and acceleration (Goldberg et al. 2012). Fish have 3 pairs of otoliths: the sagittae, lapilli and asterisci. The saccular otoliths (sagittae) are generally thought to be involved in hearing and the utricular otoliths (lapilli) in vestibular function (Platt 1983, Riley \& Moorman 2000, Straka \& Dieringer 2004). Otoliths are approximately 3 times denser than the fish body, causing them to lag the movement of the underlying sensory epithelium during acceleration. Movement of the otolith relative to the hair cells causes the latter to bend and send mechanically induced signals related to orientation and acceleration to the brainstem (Popper et al. 2005).

Fish have evolved with otoliths optimized for their motor activity and environment. Mathematical models of otolith displacement by Lychakov \& Rebane (2000) suggest that there are ecomorphological adaptations to otolith morphology that are a result of the ecology and behavior of fish. For example, the otoliths of pelagic fish are relatively small and the fish only moderately sensitive to acceleration, because they experience a limited and relatively uniform range of acceleration while swimming in an unobstructed environment. Conversely, darting demersal fish that accelerate rapidly have larger otoliths and the fish are more sensitive to acceleration. In general, models predict that larger otoliths move more and with a longer lag than smaller otoliths in response to stimuli.

Given the ecological constraints on otolith morphology for optimal functioning, deviations from the ideal morphology can negatively affect fish. For example, fish with naturally asymmetric otoliths experience impaired auditory (Gagliano et al. 2008) and vestibular (Helling et al. 2003) functioning. Furthermore, experimentally enlarged utricular otoliths of zebrafish Danio rerio acquired the sense of sound (Inoue et al. 2013). In the context of OA, larval cobia Rachycentron canadum reared at $2100 \mu$ atm $p \mathrm{CO}_{2}$ and possessing larger sagittae are predicted to experience a $50 \%$ increase in hearing range compared to control larvae (Bignami et al. 2013a). Therefore, it might be expected that changes to the lapilli would result in altered vestibular functioning.

The vestibulo-ocular reflex (VOR) is a compensatory eye rotation used to maintain visual acuity during self-motion (Goldberg et al. 2012). The precision of VOR performance is commonly measured by 2 variables: gain, the ratio of eye amplitude to head amplitude, and phase shift, the temporal synchrony between head and eye movements (Goldberg et al. 2012). The VOR is stimulated by the movements of the otoliths and endolymph in the semi-circular canals. It comprises a '3-neuron arc', in which primary afferent neurons convey signals from sensory hair cells to secondary vestibular neurons in the vestibular nuclei in the brainstem, which in turn project to ocular motoneurons that innervate the extraocular muscles of the eyes (Szentagothai 1950, Goldberg et al. 2012). The result is a counter-rotation of the eyes of equal amplitude and opposite velocity to head movement, in order to stabilize images on the retina in relation to the Earth's geoid.

The VOR is plastic, meaning that it can maintain a modified state for long periods of time without reinforcement (Miles \& Lisberger 1981). For example, when head movement results in image motion, the visual system sends error messages in the form of retinal slip signals (Miles \& Lisberger 1981). Together with the vestibular signals, these signals are processed in the cerebellum to adjust the activity of the vestibular nuclei neurons in order to modify the gain (Miles \& Lisberger 1981). In this way, the VOR operates as an open-loop system and requires calibration by the visual system (Miles \& Lisberger 1981). It is not until $3 \mathrm{~d}$ post-fertilization (dpf) that zebrafish begin to demonstrate a VOR in response to rotation around an Earth-horizontal axis at a range of frequencies (Riley \& Moorman 2000, Mo et al. 2010, Bianco et al. 2012). The gain of the VOR is low $(<0.5)$ for newly hatched animals and increases through ontogeny, eventually approaching a value of 1 (full compensation) for adult goldfish (Wallman et al. 1982, Pastor et al. 1992). The VOR of fish may be more plastic than most other vertebrates (Pastor et al. 1992) as, unlike other vertebrates, fish possess otoliths that grow continuously throughout their lifetime (Pannella 1971). This fact requires that the VOR be constantly recalibrated during otolith growth. 
Young fish larvae provide the opportunity to study the utricular otoliths as independent transducers of vestibular information because the semi-circular canals are not functional due to their small size (Beck et al. 2004, Lambert et al. 2008). Therefore, the VOR is solely activated by the utricular otoliths. Furthermore, the contribution of the vestibular system to the VOR can be studied in isolation from that of the visual system by performing experiments in the dark (Beck et al. 2004).

The VOR may be a particularly important behavioral response for first-feeding fish larvae. Many species of temperate fish, including white seabass Atractoscion nobilis, spawn pelagic eggs that hatch within a few days and produce yolk-bearing larvae (Moser et al. 1983). Soon after yolk absorption, larvae must find abundant and suitable planktonic prey, or starve (Hjort 1926). Ingestion of prey is the end result of encounter, pursuit, attack and capture processes (MacKenzie \& Kiørboe 1995). The dynamics of these processes are influenced by small-scale turbulence due to the small size of the larvae and their prey (MacKenzie \& Kiørboe 1995). Therefore, the VOR may play an important role in the ability of larvae to assume and maintain an attack position, and successfully capture prey in a turbulent environment.
We hypothesized that elevated $p \mathrm{CO}_{2}$ would increase the size of the utricular otoliths. A schematic of our experiment and hypotheses is shown in Fig. 1. Assuming that larger otoliths experience a larger displacement and lag than smaller otoliths (Lychakov \& Rebane 2000, Bignami et al. 2013a), we hypothesized that the gain and phase shift of the VOR are increased under elevated $p \mathrm{CO}_{2}$. We tested these hypotheses by rearing larval white seabass under elevated $p \mathrm{CO}_{2}$ (2500 $\mu \mathrm{atm}$ ) and measuring the area of the utricular otoliths, and the gain and phase shift of the VOR.

\section{MATERIALS AND METHODS}

\section{Data collection}

Fish

Fertilized eggs of white seabass Atractoscion nobilis were obtained the morning after spawning occurred from the Hubbs-SeaWorld Research Institute Leon Raymond Hubbard, Jr., Marine Fish Hatchery in Carlsbad, California, USA, during 2012 to 2015. Eggs that appeared healthy (undamaged, single oil globule) upon microscopic inspection were
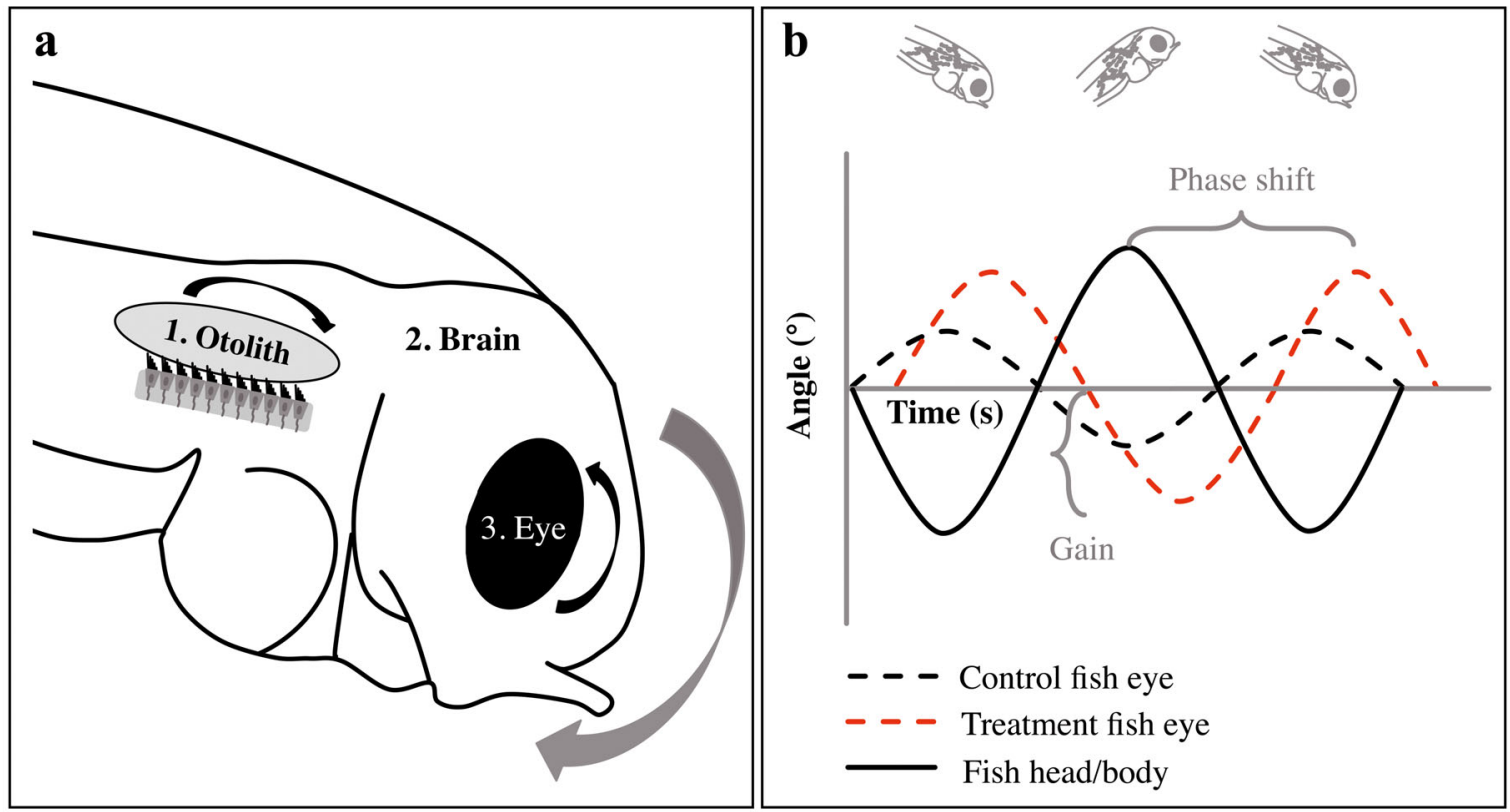

Fig. 1. Schematic of larval fish vestibulo-ocular reflex (VOR) and our hypotheses. (a) Fish larvae are rotated about an Earthhorizontal axis (gray arrow). The denser otolith lags the larva body, including the macula with sensory hair cells on which it rests. This causes the hair cells to bend posteriorly ( 1 and black arrow). Signals from the hair cells are transmitted to the vestibular nuclei in the brainstem (2). These signals are relayed to the extraocular muscles of the eye, resulting in a counter-rotation (3 and black arrow). (b) Angles of the body/head and eye. See 'Introduction' for definitions of gain and phase shift. We hypothesize that larvae reared at $2500 \mu \mathrm{atm} p \mathrm{CO}_{2}$ (treatment) would have increased gain and phase shift compared to larvae reared at $400 \mu \mathrm{atm}$ 
selected for experiments. Eggs hatch at $\sim 2$ dpf and larvae deplete their yolk sac and begin to feed at $\sim 4$ to $5 \mathrm{dpf}$ (Moser et al. 1983).

\section{Experimental system}

The experimental system from Checkley et al. (2009) was used and includes 2 (1 control, 1 treatment) or 4 ( 2 control, 2 treatment) water-jacketed, $5 \mathrm{l}$ glass vessels with jacket water maintained at $18.0^{\circ} \mathrm{C}$. Vessels were bubbled with gas certified to contain a known mixture of air and $\mathrm{CO}_{2}$ at a rate of $60 \mathrm{ml} \mathrm{min} \mathrm{m}^{-1}$ and equilibrated 1 to $2 \mathrm{~d}$ before experiments commenced. In each experiment, 200 eggs were introduced into fully equilibrated control (400 jatm $\left.p \mathrm{CO}_{2}\right)$ or treatment (2500 $\mu$ atm $p \mathrm{CO}_{2}$ ) vessels at $\sim 12 \mathrm{~h}$ post-fertilization.

At the termination of each experiment, seawater samples from each vessel were collected in $250 \mathrm{ml}$ polyethylene terephthalate bottles and fixed with $100 \mu \mathrm{l}$ of saturated mercuric chloride for the analysis of total alkalinity $\left(A_{\mathrm{T}}\right)$ and dissolved inorganic carbon (DIC) by open-cell potentiometric titration and coulometry, respectively. Conductivity-based salinity was also measured. The software CO2Calc (http://cdiac. ornl.gov/ftp/co2sys) was used to estimate $\mathrm{pH}$ and $p \mathrm{CO}_{2}$ from measured $A_{\mathrm{T}}$ and DIC.

\section{OS experiments}

Two OS experiments, OS 1 and OS 2, were performed to investigate the effects of elevated $p \mathrm{CO}_{2}$ on the size of the saccular and utricular otoliths of larvae at $7 \mathrm{dpf}$. In each experiment, there was 1 control

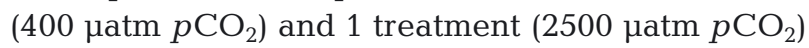
vessel.

At 7 dpf, larvae were preserved in 95\% ethanol for otolith removal. Sagittae and lapilli were removed with minuten needles under cross-polarized light with the aid of a dissecting microscope. Otoliths were mounted using double-sided black carbon tape onto scanning electron microscopy (SEM) stubs, sputtercoated with iridium for $8 \mathrm{~s}$ and imaged at high magnification $(\times 1500$ to 3000$)$ and high resolution $(2 \mathrm{~nm})$ using SEM (Phillips XL30 ESEM). Otoliths in SEM images, calibrated to magnification, were traced using ImageJ (National Institutes of Health), and area and circularity $\left(4 \pi \times\right.$ area/perimeter $\left.{ }^{2}\right)$ estimated. Otolith identity was masked during measurements. Estimates of otolith mass were obtained assuming that otolith density is constant and that volume is proportional to area ${ }^{1.5}$ (Checkley et al. 2009).

\section{VOR experiments}

Three VOR experiments, VOR 1, VOR 2 and VOR 3 , were performed to test for effects of elevated $p \mathrm{CO}_{2}$ on the VOR of larvae at $4 \mathrm{dpf}$. VOR 1 had 1 control

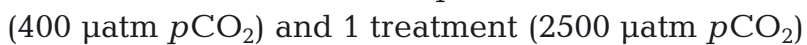
vessel, while VOR 2 and VOR 3 each had 2 control and 2 treatment vessels. However, high mortality or the inability to analyze some of the VOR videos, due to larva movement or poor lighting, led to data from larvae in only 1 of the treatment vessels for VOR 2 and only 1 of the control vessels for VOR 3 (see Table S1 in the Supplement at www.int-res.com/ articles/suppl/m553p173_supp/).

At $4 \mathrm{dpf}$, a fish larva was removed by pipette from a vessel and partially immobilized in a Pasteur pipette by embedding the posterior end (pectoral fins to caudal fin) in $2 \%$ low-gelling-temperature agarose, while the anterior end (head to pectoral fins) was surrounded by seawater. This process allowed unrestricted eye movement while restricting body movement during video recording. Several drops of food coloring were added to the agarose to aid in visual confirmation that no agarose hardened around the eye. Embedding was done with the aid of a dissecting microscope.

The pipette containing the embedded larva was then mounted on a micromanipulator attached to an automatic test tube rocker (Barnstead M48725) that was repurposed as a tilting platform. Using the micromanipulator, the pipette was positioned so that the head of the larva was aligned near the axis of rotation, and the anterior-posterior axis of the larva was perpendicular to the axis of rotation. Positioning of the larva slightly above the center of rotation of the platform resulted in a small amount of translation in addition to rotation of the larva.

Larvae were pitch-tilted (i.e. nose up and down) $24.4 \pm 0.8^{\circ}$ (mean $\pm \mathrm{SD}$ ) at $0.28 \mathrm{~Hz}$, consistent with prior studies of goldfish (Pastor et al. 1992) and zebrafish (Mo et al. 2010, Bianco et al. 2012). A gyroscope (Sparkfun LPY503AL) was attached to the platform along its axis of rotation to measure angular velocity, which was recorded by an Arduino Duo microcontroller.

A USB 2.0 monochrome digital video camera (Point Grey CMLN-13S2M-CS) mounted to a Mitutoyo 5x long working distance lens (Edmund Optics 46-143) was used to record movement of the left eye of the larva at 15 frames $\mathrm{s}^{-1}$ for a total of 500 frames, or 33 s. Larvae were trans-illuminated with four $980 \mathrm{~nm}$ infrared LEDs. Since larvae are mostly transparent, this illumination increased the contrast be- 
tween the eye and body for optimal image processing. All experiments were conducted in a dark box.

\section{Data analysis}

Platform

The platform was sinusoidally rotated $24^{\circ}$ in each direction with constant peak velocity of $5^{\circ} \mathrm{s}^{-1}$ at a frequency of $0.28 \mathrm{~Hz}$. The gyroscope measured angular velocity $\left({ }^{0} \mathrm{~s}^{-1}\right)$ of the platform every $0.2 \mathrm{~s}$. Relative angular position was calculated by cumulatively summing angular velocity. Relative angular position was multiplied by a conversion factor, calculated as the ratio of the maximum angle of the platform $\left( \pm 24^{\circ}\right)$ to the maximum angular position value, to obtain the angular position of the platform.

\section{Fish eye}

Variation in the quality of the video recordings necessitated an approach to eye angle quantification different from that previously used (Beck et al. 2004, Mo et al. 2010). Video analysis was performed using custom software written in MATLAB (Mathworks).

Briefly, images were converted from grayscale to binary using a threshold value that demarcated the eye from the remaining fish body as well as possible. A section of the eye with a clear edge was selected as the region of interest, and the angle of rotation of this section was calculated using Radon transform (Deans 1993). This angle represents the angle of the entire eye. For more information and an illustration of the image analysis process using a sample video frame see Fig. S1 and the corresponding full video (Video S1, both in the Supplement at www.int-res.com/articles/suppl/m553p173_supp/) for more information.

\section{Gain and phase shift}

The VOR was measured by calculating the gain and phase shift of the eye of the fish larvae during movement of the platform. An example of the platform and eye data for a larva is shown in Fig. 2. The eye and platform data were fitted with a sinusoidal function in a least-squares framework. Nonlinear optimization was performed using the function 'fminsearch' in MATLAB, which outputs the values of amplitude, period and phase that parameterized the best-fit sinusoidal model. Depending on the initial direction of the platform, $180^{\circ}$ were added to the phase, so that a phase shift of $0^{\circ}$ was equal to the fish eye and platform moving $180^{\circ}$ out of phase. This was necessary, given the coordinates we defined for the movement of the platform and fish. By convention, phase shifts are expressed relative to $180^{\circ}$. Gain was calculated as the ratio of the absolute value of the amplitude of the eye sinusoid to that of the platform sinusoid. Phase shift was calculated as the difference between the phase of the eye sinusoid and the phase of the platform sinusoid, constrained between -90 and $270^{\circ}$ by additions or subtractions of $360^{\circ}$. Positive values of phase shift are termed phase lags and negative values are termed phase leads.

\section{Statistics}

OS and VOR experiments were analyzed using 2way analysis of variance (ANOVA) with either otolith area, otolith circularity, gain or phase shift as the response variable, and $p \mathrm{CO}_{2}$ and experiment as the 2 factors. We acknowledge that observations within each control or treatment group of each experiment are not independent because larvae in each group were from either 1 or 2 experimental containers. Thus, our result that the ANOVA did not show significant effects of either $p \mathrm{CO}_{2}$ or experiment on either gain or phase shift is conservative.

Gain data of VOR experiments and otolith circularity data of OS experiments were log-transformed to satisfy the assumption of normality required for ANOVA. Normality and homoscedasticity of data were tested using Shapiro-Wilks and Bartlett's tests. Results were considered significant at $\mathrm{p}<0.05$.

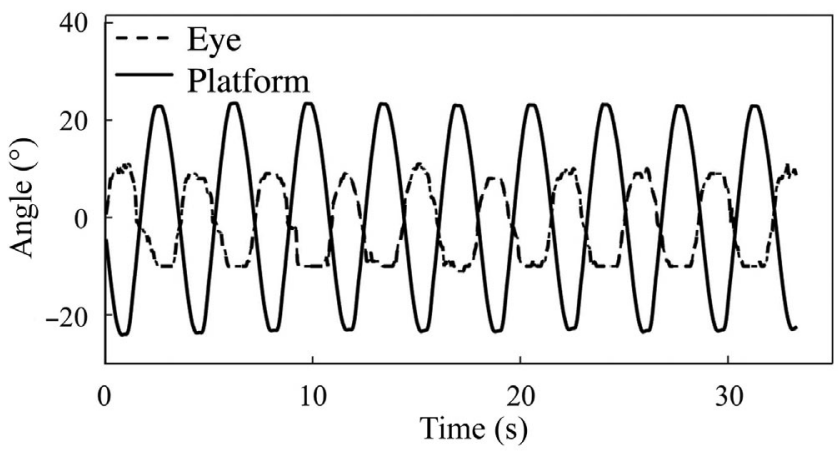

Fig. 2. Example of the platform and eye data for a fish larva reared at $2500 \mu \mathrm{atm} p \mathrm{CO}_{2}$. Solid and dashed sinusoids represent the movement of the platform and thus fish body/ head, and eye of the fish larva, respectively. These data are from the fish larva in Video S1 in the Supplement at www.int-res.com/articles/suppl/m553p173_supp/ 
Empirical cumulative distribution functions (CDFs) of the gain of control and treatment larvae were calculated, and differences in the CDFs were tested using a Kolmogorov-Smirnov (K-S) test. Statistical analyses were performed in MATLAB (Mathworks). Summary statistics are reported as mean $\pm \mathrm{SE}$.

\section{RESULTS}

\section{Seawater carbonate chemistry}

In general, control and treatment vessels in OS and VOR experiments accurately represented target $p \mathrm{CO}_{2}$. Mean $A_{\mathrm{T}}$, DIC and salinity were consistent among control and treatment vessels within and between OS and VOR experiments (Table 1).

\section{OS experiments}

$p \mathrm{CO}_{2}$ significantly affected the size of saccular and utricular otoliths at $7 \mathrm{dpf}$ (Fig. 3, Table 2). Sagittae and lapilli were 14 to $20 \%$ and 37 to $39 \%$ larger in area for treatment larvae than control larvae, respectively (Table 2). Two-way ANOVAs showed an effect of experiment on saccular and utricular OS (ANOVA, p < 0.001; Table 3). There was a weak, but significant, interaction between $p \mathrm{CO}_{2}$ and experiment (ANOVA, $\mathrm{p}=0.02$; Table 3 ) for sagittae. Residuals of the area of saccular otoliths were non-normal (Shapiro-Wilks, $\mathrm{p}<$

Table 1. Seawater carbonate chemistry measurements for otolith size (OS) and vestibulo-ocular reflex (VOR) experiments. Values are measured salinity, temperature, total alkalinity $\left(A_{\mathrm{T}}\right)$ and dissolved inorganic carbon (DIC). Partial pressure of $\mathrm{CO}_{2}\left(p \mathrm{CO}_{2}\right)$ was estimated using the software $\mathrm{CO} 2 \mathrm{Calc}$

\begin{tabular}{|lccccc|}
\hline Expt & Salinity & $\begin{array}{c}\text { Temperature } \\
\left({ }^{\circ} \mathrm{C}\right)\end{array}$ & $\begin{array}{c}A_{\mathrm{T}} \\
\left(\mu \mathrm{mol} \mathrm{kg}{ }^{-1}\right)\end{array}$ & $\begin{array}{c}\mathrm{DIC} \\
\left(\mu \mathrm{mol} \mathrm{kg}{ }^{-1}\right)\end{array}$ & $\begin{array}{c}p \mathrm{CO}_{2} \\
(\mu \mathrm{atm})\end{array}$ \\
\hline Control & & & & & \\
OS 1 & 33.61 & 18.0 & 2245 & 2025 & 416 \\
OS 2 & 33.68 & 18.0 & 2246 & 2030 & 426 \\
VOR 1 & 33.61 & 18.1 & 2233 & 2029 & 450 \\
VOR 2 & 33.63 & 18.0 & 2255 & 2053 & 465 \\
VOR 2 & 33.62 & 18.0 & 2256 & 2056 & 468 \\
VOR 3 & 33.62 & 18.0 & 2249 & 2045 & 455 \\
Treatment & & & & & \\
OS 1 & 33.60 & 18.0 & 2242 & 2274 & 2468 \\
OS 2 & 33.65 & 18.0 & 2248 & 2279 & 2465 \\
VOR 1 & 33.57 & 18.0 & 2239 & 2258 & 2230 \\
VOR 2 & 33.63 & 18.0 & 2254 & 2282 & 2407 \\
VOR 3 & 33.65 & 18.0 & 2251 & 2287 & 2543 \\
VOR 3 & 33.65 & 18.1 & 2251 & 2278 & 2400 \\
\hline
\end{tabular}

0.001) due to 1 small value, but variance was homoscedastic (Bartlett's, p > 0.05). Residuals of the area of utricular otoliths were normal (Shapiro-Wilks, p > 0.05) and variance was homoscedastic (Bartlett's, p > 0.05). Circularity of saccular and utricular otoliths was unaffected by $p \mathrm{CO}_{2}$ (ANOVA, $\left.\mathrm{p}>0.05\right)$, so that otolith area was increased for treatment larvae compared to control larvae, while shape was unchanged.

\section{VOR experiments}

Turbulence

We calculated the turbulent dissipation rate equivalent to that of the environment of the larvae as they were pitch-tilted during experiments to relate our experimental conditions to the turbulent conditions that pelagic larvae experience in the upper surface ocean. Using the Kolmogorov time scale equation $\tau=$ $(v / \varepsilon)^{1 / 2}$, where $\tau$ is approximately half of the period of the platform $(2 \mathrm{~s})$, and $v$ is the kinematic viscosity of seawater $\left(10^{-6} \mathrm{~m}^{2} \mathrm{~s}^{-1}\right)$, we calculated a turbulent dissipation rate, $\varepsilon$, of $2.5 \times 10^{-7} \mathrm{~m}^{2} \mathrm{~s}^{-3}$.

\section{Gain and phase shift}

Gain of larvae reared at $2500 \mu$ atm $p \mathrm{CO}_{2}$ was consistently larger, but not significantly so, than larvae reared at $400 \mu$ atm $p \mathrm{CO}_{2}$ (Table 4). Gain and phase shift data for individual fish in each VOR experiment are available (see Table S1 in the Supplement). A comparison of the CDFs for control and treatment larvae revealed that $90 \%$ of control larvae had a gain <0.6, whereas this value was 0.9 for treatment larvae. A single treatment larva overcompensated for head movement with a gain $>1$. Despite the tendency for treatment larvae to exhibit a larger gain compared to control larvae, a 2-way ANOVA yielded non-significant results for $p \mathrm{CO}_{2}$ (ANOVA, $\mathrm{p}>0.05$; Table 5) and a K-S test found non-significant differences in the CDFs (K-S, p > 0.1). There was no effect of experiment (ANOVA, p > 0.05) or the interaction of experiment and $p \mathrm{CO}_{2}$ (ANOVA, p > 0.05; Table 5) on gain. Residuals for gain approximated a normal distribution (Shapiro-Wilks, p > 0.05) and variance was homoscedastic (Bartlett's, p > 0.05).

Phase shift did not differ significantly between control and treatment larvae (Table 4). 

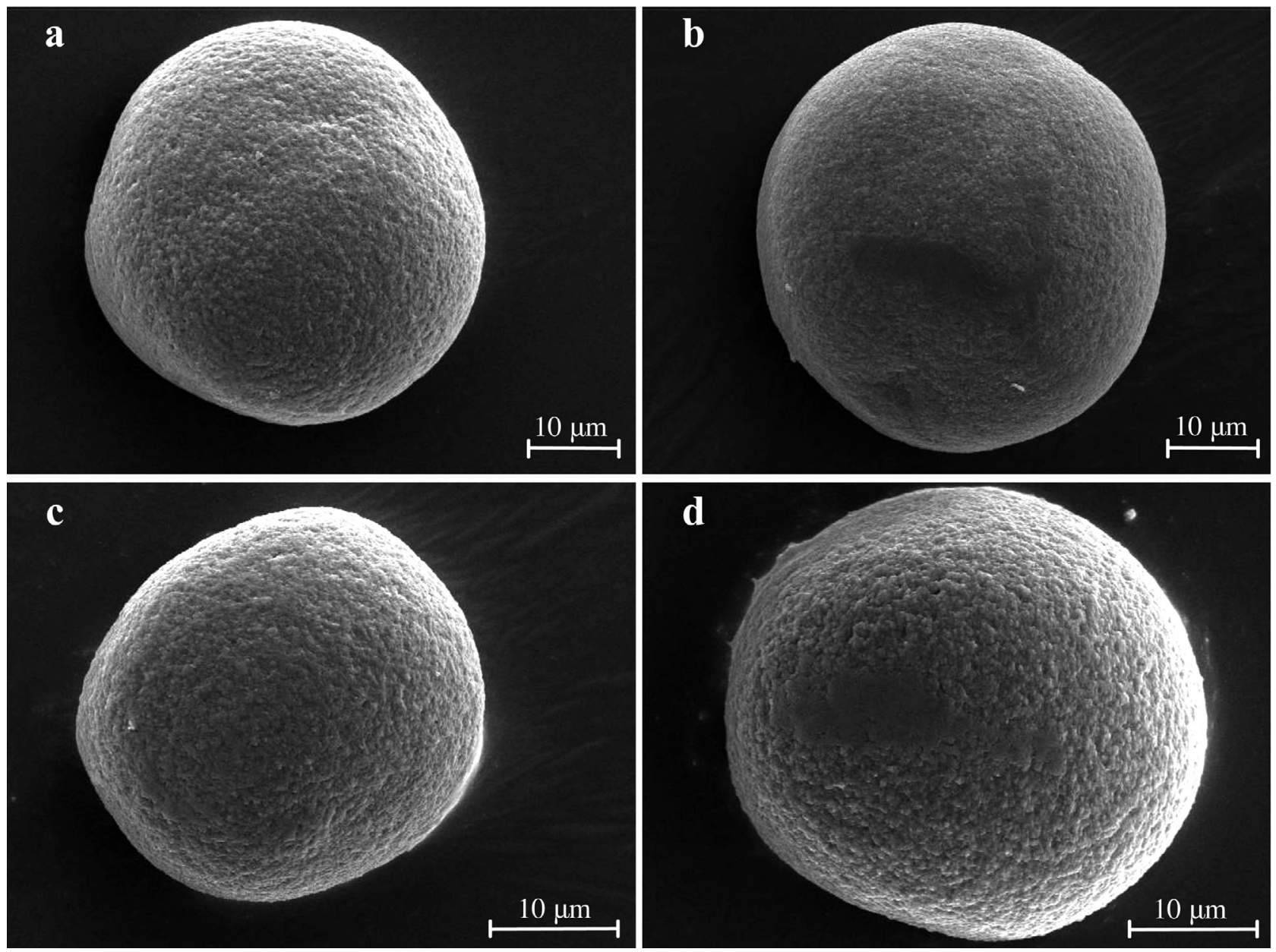

Fig. 3. SEM images of the saccular and utricular otoliths of $7 \mathrm{~d}$ post-fertilization (dpf) white seabass larvae reared at control $(400 \mu \mathrm{atm})$ and treatment $(2500 \mu \mathrm{atm}) \mathrm{pCO}_{2}$. (a) Control sagittae. (b) Treatment sagittae. (c) Control lapilli. (d) Treatment lapilli. Saccular and utricular otoliths were imaged at $\times 1750$ and $\times 2500$, respectively

Table 2. Results of otolith size (OS) experiments on $7 \mathrm{~d}$ postfertilization (dpf) larvae. Values are target $p \mathrm{CO}_{2}$, number of otoliths measured $(\mathrm{N})$, mean otolith area $\pm \mathrm{SE}$ and the ratio of otolith areas of treatment $(2500 \mu \mathrm{atm})$ to control $(400 \mu \mathrm{atm})$ larvae. ${ }^{*} \mathrm{p}<0.05$

\begin{tabular}{|lcccc|}
\hline Expt & $\begin{array}{c}p \mathrm{CO}_{2} \\
(\mu \mathrm{atm})\end{array}$ & $\mathrm{N}$ & $\begin{array}{c}\text { Mean otolith } \\
\text { area }\left(\mu \mathrm{m}^{2}\right)\end{array}$ & $\begin{array}{c}\text { Ratio of } \\
\text { otolith areas }\end{array}$ \\
\hline Sagittae & & & & \\
OS 1 & 400 & 13 & $715 \pm 19$ & \\
OS 1 & 2500 & 12 & $982 \pm 17$ & $1.14^{*}$ \\
OS 2 & 400 & 18 & $762 \pm 19$ & $1.20^{*}$ \\
OS 2 & 2500 & 20 & $1061 \pm 17$ & \\
Lapilli & & & & $1.37^{*}$ \\
OS 1 & 400 & 15 & $1454 \pm 18$ & $1.39^{*}$ \\
OS 1 & 2500 & 15 & $1663 \pm 18$ & \\
OS 2 & 400 & 15 & $1609 \pm 27$ & \\
OS 2 & 2500 & 16 & $1936 \pm 29$ & \\
\hline
\end{tabular}

In general, phase shifts were smaller for treatment larvae compared to control larvae. Both control and treatment larvae experienced phase leads and lags, although the mean across experiments was a small phase lead (Table 4). There was no effect of $p \mathrm{CO}_{2}$, experiment, or the interaction of experiment and $p \mathrm{CO}_{2}$ (ANOVA, $\left.\mathrm{p}>0.05\right)$ on phase shift (Table 5). Residuals of phase shift were non-normal (ShapiroWilks, $p=0.04$ ) and variance was homoscedastic (Bartlett's, p > 0.05).

\section{DISCUSSION}

We reared white seabass larvae at present

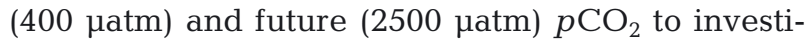
gate the effects of elevated $p \mathrm{CO}_{2}$ on otolith morphology and functionality. We found a significant effect 
Table 3. Results of 2-way ANOVA tests for otolith size (OS) experiments. The response variables are saccular and utricular otolith areas of $7 \mathrm{~d}$ post-fertilization larvae. Factors are $p \mathrm{CO}_{2}$ with 2 levels (400 and $2500 \mu \mathrm{atm}$ ) and experiment with 2 levels (OS 1 and OS 2). Values are degrees of freedom (df), mean squares (MS), F-statistic and p-value

\begin{tabular}{|lccrc|}
\hline & df & MS & $F$ & $p$ \\
\hline Sagittae & & & & \\
$p \mathrm{CO}_{2}$ & 1 & 1090000 & 126.68 & $<0.001$ \\
Expt & 1 & 694000 & 80.47 & $<0.001$ \\
$p \mathrm{CO}_{2} \times$ Expt & 1 & 53500 & 6.20 & $<0.05$ \\
Error & 57 & 8630 & & \\
Total & 60 & & & \\
Lapilli & & & & \\
$p \mathrm{CO}_{2}$ & 1 & 1200000 & 226.21 & $<0.001$ \\
Expt $_{p \mathrm{CO}_{2}} \times$ Expt & 1 & 60000 & 11.27 & $<0.01$ \\
Error & 1 & 3990 & 0.75 & 0.39 \\
Total & 59 & 5320 & & \\
& 62 & & & \\
\hline
\end{tabular}

Table 4. Results of vestibulo-ocular reflex (VOR) experiments for $4 \mathrm{~d}$ post-fertilization larvae. Values are target $p \mathrm{CO}_{2}$, number of larvae tested $(\mathrm{N})$, mean gain and phase shift $\pm \mathrm{SE}$

\begin{tabular}{|lcccc|}
\hline Expt & $\begin{array}{c}p \mathrm{CO}_{2} \\
(\mu \mathrm{atm})\end{array}$ & $\mathrm{N}$ & Mean gain & $\begin{array}{c}\text { Mean phase } \\
\text { shift }\left(\mu \mathrm{m}^{2}\right)\end{array}$ \\
\hline Control & & & & \\
VOR 1 & 400 & 5 & $0.30 \pm 0.09$ & $7.4 \pm 9.3$ \\
VOR 2 & 400 & 6 & $0.30 \pm 0.04$ & $-10.8 \pm 4.4$ \\
VOR 3 & 400 & 9 & $0.30 \pm 0.05$ & $-7.6 \pm 8.2$ \\
Treatment & & & & \\
VOR 1 & 2500 & 5 & $0.37 \pm 0.13$ & $-3.0 \pm 11.4$ \\
VOR 2 & 2500 & 9 & $0.39 \pm 0.10$ & $1.6 \pm 5.4$ \\
VOR 3 & 2500 & 14 & $0.40 \pm 0.05$ & $-6.1 \pm 9.0$ \\
\hline
\end{tabular}

Table 5. Results of 2-way ANOVA tests for vestibulo-ocular reflex (VOR) experiments. The response variables are gain and phase shift of $4 \mathrm{~d}$ post-fertilization larvae. Factors are $p \mathrm{CO}_{2}$ with 2 levels (400 and $2500 \mu \mathrm{atm}$ ) and experiment with 3 levels (VOR 1, VOR 2 and VOR 3). Values are degrees of freedom (df), mean squares (MS), F-statistic and p-value

\begin{tabular}{|lcccc|}
\hline & df & MS & $F$ & $p$ \\
\hline Gain & & & & \\
$p \mathrm{CO}_{2}$ & 1 & 0.85 & 3.00 & 0.09 \\
Expt & 2 & 0.39 & 1.39 & 0.26 \\
$p \mathrm{CO}_{2} \times$ Expt & 2 & 0.29 & 1.04 & 0.36 \\
Error & 42 & 0.28 & & \\
Total & 47 & & & \\
Phase shift & & & & \\
$p \mathrm{CO}_{2}$ & 1 & 14.35 & 0.02 & 0.88 \\
Expt & 2 & 285.64 & 0.45 & 0.64 \\
$p \mathrm{CO}_{2} \times$ Expt & 2 & 382.45 & 0.61 & 0.55 \\
Error & 42 & 632.11 & & \\
Total & 47 & & & \\
\hline
\end{tabular}

of $p \mathrm{CO}_{2}$ on otolith area and non-significant effect on VOR. Our study provides new insight into the functional consequences of larger otoliths in the larvae of several species of fish reared at high $p \mathrm{CO}_{2}$.

The sagittae and lapilli of $7 \mathrm{dpf}$ larvae reared at elevated $p \mathrm{CO}_{2}$ were 14 to $20 \%$ and 37 to $39 \%$ larger in area, respectively, and estimated to be 21 to $30 \%$ and 55 to $59 \%$ greater in mass than those of control larvae. We did not measure the dry mass of larvae, but assumed it to be similar for control and treatment larvae, based on the results of Checkley et al. (2009), which showed that the dry mass of white seabass larvae at 7 to $8 \mathrm{dpf}$ and reared at 380 atm $p \mathrm{CO}_{2}$ was not statistically significantly different from that of those reared at $2500 \mu \mathrm{atm} \mathrm{CO}_{2}$. Our results are consistent with the increase in saccular otolith area of 7 to $17 \%$ and estimated mass of 10 to $26 \%$ reported by Checkley et al. (2009). Similarly, the otoliths of cobia (Bignami et al. 2013a,b), Atlantic cod (Maneja et al. 2013a), clownfish (Munday et al. 2011) and seabream (Réveillac et al. 2015) are 10 to $46 \%$ larger when larvae are raised under acidified conditions (700 to 4653 jatm).

We characterized the VOR of white seabass, a previously untested species, at the time of first feeding (4 dpf). Larval fish-prey dynamics are influenced by turbulence due to the small size of both larvae and planktonic prey (MacKenzie \& Kiørboe 1995). The integrity of the VOR may be most important during the 'critical period' when first-feeding larvae must locate and capture prey. The mean gain (0.30) and phase shift $\left(-4.8^{\circ}\right)$ we observed for $4 \mathrm{dpf}$ white seabass are comparable to those of $4 \mathrm{dpf}$ zebrafish (gain, 0.33 ; phase shift, approximately $-5^{\circ}$ ) as reported by Bianco et al. (2012). A higher mean gain of 0.49 was reported by Mo et al. (2010), also for zebrafish larvae. Given the small size of white seabass larvae at $4 \mathrm{dpf}$ (3.7 mm standard length), it is likely that the VOR at this stage is driven solely by the sensory input of the utricular otoliths (Beck et al. 2004, Lambert et al. 2008).

$p \mathrm{CO}_{2}$ did not significantly affect the VOR of larvae. We offer 4 possible explanations for the non-significant treatment effect. First, the VOR of larvae was tested under conditions that reflect a relatively calm surface ocean. We estimated the turbulent dissipation rate equivalent to that of the environment of the larvae in our experiments to be $2.5 \times 10^{-7} \mathrm{~m}^{2} \mathrm{~s}^{-3}$. Turbulence dissipation rates in the surface water of the ocean where pelagic larvae reside span several orders of magnitude, from $10^{-8}$ to $10^{-2} \mathrm{~m}^{2} \mathrm{~s}^{-3}$ (Mackenzie \& Leggett 1993, Horne et al. 1996). Therefore, our stimulus may not have produced the accelera- 
tions to which larvae are adapted and which cause significant otolith displacement. Subjecting larvae to more turbulent conditions with greater accelerations will increase otolith stimulation. The difference between otolith displacement for control and treatment larvae with different sized otoliths, and thus resulting VOR, may be greater at higher stimulus velocities. Therefore, the VOR of white seabass larvae, and the larvae of other species, should be tested under a range of turbulence conditions that fish larvae may experience in nature in future experiments.

Second, the larger-sized otoliths of treatment larvae may be within the natural range of variation of otoliths that allows for normal functioning of the VOR. OS is known to vary with species (Paxton 2000) and in response to environmental conditions (Marshall \& Parker 1982, Mosegaard et al. 1988). The natural variation in OS could also explain the lack of $p \mathrm{CO}_{2}$ effect on the swimming kinetics and performance of larval cobia (Bignami et al. 2013b) and Atlantic cod (Maneja et al. 2013b) with enlarged otoliths, and of Atlantic herring with smaller otoliths (Maneja 2012, Maneja et al. 2015). Because the VOR is calibrated to OS and displacement, as occurs during development, it is perhaps not surprising that the gain and phase shift of the VOR were unchanged for larvae with enlarged otoliths.

Third, it is possible that the $p \mathrm{CO}_{2}$ has not affected OS by $4 \mathrm{dpf}$. Owing to the small size of the otoliths $(<50 \mu \mathrm{m})$ at $4 \mathrm{dpf}$, removal and manipulation onto an SEM stub was not possible. For this reason, we were unable to measure OS at the same age as we performed VOR experiments. It is also possible that larvae compensated for the negative effects of $p \mathrm{CO}_{2}$, thereby maintaining a normal VOR at an energetic cost. A reduction in the size of the yolk sac or oil globule of fish larvae when reared at elevated $p \mathrm{CO}_{2}$, as experienced by yellowtail kingfish Seriola lalandi, orange clownfish Amphiprion percula and summer flounder Paralichthys dentatus, is one example of an increased energetic cost (Munday et al. 2016).

Lastly, it was suggested by Munday et al. (2016) that the slow growth and delayed development of gills and branchial acid-base regulation of temperate, pelagic spawned fish may predispose them to morphological and energetic effects of high $p \mathrm{CO}_{2}$ earlier during the larval stages than for tropical species. Behavioral effects may not manifest until the later larval stages, after the development of gills and acid-base regulation. The many negative effects of elevated $p \mathrm{CO}_{2}$ on the sensory systems and behavior of tropical reef fish larvae has been attributed to the disruption of the GABA and $\mathrm{GABA}_{\mathrm{A}}$ neurotransmit- ter and receptors (Nilsson et al. 2012, Hamilton et al. 2014, Heuer \& Grosell 2014). The resiliency of the VOR to elevated $p \mathrm{CO}_{2}$ despite the role of GABA as the primary inhibitory neurotransmitter (Spencer \& Baker 1992) suggests that white seabass larvae, and perhaps the larvae of other fish, may utilize $\mathrm{Na}^{+} / \mathrm{H}^{+}$ exchangers for acid-base regulation prior to the development of branchial $\mathrm{Cl} / \mathrm{HCO}_{3}{ }^{-}$exchange (Munday et al. 2016).

Subtle changes in the VOR were discernible in our experiments. There was a marginally significant tendency (ANOVA, $p=0.09$ ) for treatment larvae to have increased gain compared to control larvae. Further studies should explore the influence of stimulus intensity, representative of turbulence conditions, on the VOR and test other vestibular-related behaviors (e.g. counter-rolling) in the larvae of different fish species. Future studies may show effects of elevated $p \mathrm{CO}_{2}$ on the vestibular function of fish larvae.

Acknowledgements. We are grateful to Hubbs-SeaWorld Research Institute Leon Raymond Hubbard, Jr., Marine Fish Hatchery for providing fertilized white seabass eggs. This research would not have been possible without its contribution. We thank Peter Franks, Peng Sun, Sammie Wang, Stuart Sandin, Ryan Anderson and David Cervantes for assistance with turbulent dissipation rate calculations, image analysis, gyroscope data, statistics, use of SEM and carbonate chemistry analyses. We thank Martin Tresguerres, William Jones and Rebecca Asch for comments that improved the manuscript. We also thank 3 anonymous reviewers for providing us with suggestions to improve the manuscript. Animal handling and experimental procedures were approved by the University of California San Diego Institutional Animal Care and Use Committee under protocol S12161. Funding in support of this research was provided by the Academic Senate of the University of California, San Diego (UCSD) to D.M.C. and the Scripps Institution of Oceanography at UCSD to S.G.S. Support was provided from the National Science Foundation Graduate Research Fellowship Program to S.G.S. The authors declare no conflicts of interest.

\section{LITERATURE CITED}

Baumann H, Talmage SC, Gobler CJ (2012) Reduced early life growth and survival in a fish in direct response to increased carbon dioxide. Nat Clim Change 2:38-41

Beck JC, Gilland E, Tank DW, Baker R (2004) Quantifying the ontogeny of optokinetic and vestibuloocular behaviors in zebrafish, medaka, and goldfish. J Neurophysiol 92:3546-3561

Bianco IH, Ma LH, Schoppik D, Robson DN and others (2012) The tangential nucleus controls a gravito-inertial vestibulo-ocular reflex. Curr Biol 22:1285-1295

Bignami S, Enochs IC, Manzello DP, Sponaugle S, Cowen RK (2013a) Ocean acidification alters the otoliths of a pantropical fish species with implications for sensory function. Proc Natl Acad Sci USA 110:7366-7370 
Bignami S, Sponaugle S, Cowen RK (2013b) Response to ocean acidification in larvae of a large tropical marine fish, Rachycentron canadum. Glob Change Biol 19: 996-1006

> Caldeira K, Wickett M (2003) Anthropogenic carbon and ocean $\mathrm{pH}$. Nature 425:365

> Chambers RC, Candelmo AC, Habeck EA, Poach ME and others (2014) Effects of elevated $\mathrm{CO}_{2}$ in the early life stages of summer flounder, Paralichthys dentatus, and potential consequences of ocean acidification. Biogeosciences 11:1613-1626

Checkley DM Jr, Dickson AG, Takahashi M, Radich JA, Eisenkolb N, Asch R (2009) Elevated $\mathrm{CO}_{2}$ enhances otolith growth in young fish. Science 324:1683

> Chung WS, Marshall NJ, Watson SA, Munday PL, Nilsson GE (2014) Ocean acidification slows retinal function in a damselfish through interference with $\mathrm{GABA}_{\mathrm{A}}$ receptors. J Exp Biol 217:323-326

Deans SR (1993) Definition of the Radon transform. In: Deans SR (ed) The Radon transform and some of its applications. Dover Publications, New York, NY, p 55-61

> Devine BM, Munday PL, Jones GP (2012) Rising $\mathrm{CO}_{2}$ concentrations affect settlement behaviour of larval damselfishes. Coral Reefs 31:229-238

> Doney SC, Fabry VJ, Feely RA, Kleypas JA (2009) Ocean acidification: the other $\mathrm{CO}_{2}$ problem. Annu Rev Mar Sci 1:169-192

> Forsgren E, Dupont S, Jutfelt F, Amundsen T (2013) Elevated $\mathrm{CO}_{2}$ affects embryonic development and larval phototaxis in a temperate marine fish. Ecol Evol 3: 3637-3646

> Franke A, Clemmesen C (2011) Effect of ocean acidification on early life stages of Atlantic herring (Clupea harengus L.). Biogeosciences 8:3697-3707

Frommel AY, Maneja R, Lowe D, Malzahn AM and others (2012) Severe tissue damage in Atlantic cod larvae under increasing ocean acidification. Nat Clim Change 2:42-46

Gagliano M, Depczynski M, Simpson SD, Moore JA (2008) Dispersal without errors: symmetrical ears tune into the right frequency for survival. Proc R Soc B 275:527-534

Goldberg JM, Wilson VJ, Cullen KE, Angelaki DE and others (2012) The vestibular system: a sixth sense. Oxford University Press, New York, NY

> Hamilton TJ, Holcombe A, Tresguerres $\mathrm{M}$ (2014) $\mathrm{CO}_{2}$ induced ocean acidification increases anxiety in rockfish via alteration of $\mathrm{GABA}_{\mathrm{A}}$ receptor functioning. Proc R Soc B 281:20132509

Helling K, Hausmann S, Clarke A, Scherer H (2003) Experimentally induced motion sickness in fish: possible role of the otolith organs. Acta Otolaryngol 123:488-492

Heuer RM, Grosell M (2014) Physiological impacts of elevated carbon dioxide and ocean acidification on fish. Am J Physiol Regul Integr Comp Physiol 307:R1061-R1084

Hjort (1926) Fluctuations in the year classes of important food fishes. J Cons Int Explor Mer 1:1-38

Hönisch B, Ridgwell A, Schmidt DN, Thomas E and others (2012) The geological record of ocean acidification. Science 335:1058-1063

> Horne EPW, Loder JW, Naimie CE, Oakey NS (1996) Turbulence dissipation rates and nitrate supply in the upper water column on Georges Bank. Deep-Sea Res II 43: 1683-1712

> Houde ED (1997) Patterns and trends in larval stage growth and mortality of teleost fish. J Fish Biol 51:52-83
Inoue M, Tanimoto M, Oda Y (2013) The role of ear stone size in hair cell acoustic sensory transduction. Sci Rep 3: 2114

IPCC (2013) Climate change 2013: the physical science basis, Chapter 6. In: Stocker TF, Qin D, Plattner GK, Tignor $\mathrm{M}$ and others (eds) Contribution of working group 1 to the fifth assessment report of the Intergovernmental Panel on Climate Change. Cambridge University Press, Cambridge, p 465-544

> Lambert FM, Beck JC, Baker R, Straka H (2008) Semicircular canal size determines the developmental onset of angular vestibuloocular reflexes in larval Xenopus. J Neurosci 28:8086-8095

Lychakov DV, Rebane YT (2000) Otolith regularities. Hear Res 143:83-102

MacKenzie BR, Kiørboe T (1995) Encounter rates and swimming behavior of pause-travel and cruise larval fish predators in calm and turbulent environments. Limnol Oceanogr 40:1278-1289

> Mackenzie BR, Leggett WC (1993) Wind-based models for estimating the dissipation rates of turbulent energy in aquatic environments: empirical comparisons. Mar Ecol Prog Ser 94:207-216

Maneja RH (2012) Influence of ocean acidification on otolith calcification and behavior in fish larvae. PhD dissertation, University of Kiel

Maneja RH, Frommel AY, Geffen AJ, Folkvord A, Piatkowski U, Chang MY, Clemmesen C (2013a) Effects of ocean acidification on the calcification of otoliths of larval Atlantic cod Gadus morhua. Mar Ecol Prog Ser 477: 251-258

Maneja RH, Frommel AY, Browman HI (2013b) The swimming kinematics of larval Atlantic cod, Gadhus morhua L., are resilient to elevated seawater $p \mathrm{CO}_{2}$. Mar Biol 160: 1963-1972

Maneja RH, Frommel AY, Browman HI (2015) The swimming kinematics and foraging behavior of larval Atlantic herring (Clupea harengus L.) are unaffected by elevated $p \mathrm{CO}_{2}$. J Exp Mar Biol Ecol 466:42-48

Marshall SL, Parker SS (1982) Pattern identification in the microstructure of sockeye salmon (Oncorhynchus nerka) otoliths. Can J Fish Aquat Sci 39:542-547

Miles FA, Lisberger SG (1981) Plasticity in the vestibuloocular reflex: a new hypothesis. Annu Rev Neurosci 4: 273-299

Mo W, Chen F, Nechiporuk A, Nicolson T (2010) Quantification of vestibular-induced eye movements in zebrafish larvae. BMC Neurosci 11:110

Mosegaard H, Svedäng H, Taberman K (1988) Uncoupling of somatic and otolith growth rates in Arctic char (Salvelinus alpinus) as an effect of differences in temperature response. Can J Fish Aquat Sci 45:1514-1524

Moser HG, Ambrose DA, Busby MS, Butler JL, Sandknop EM (1983) Description of early stages of white seabass, Atractoscion nobilis, with notes on distribution. CCOFI Rep 24:182-193

Munday PL, Donelson JM, Dixson DL, Endo GGK (2009a) Effects of ocean acidification on the early life history of a tropical marine fish. Proc R Soc B 276:3275-3283

Munday PL, Dixson DL, Donelson JM, Jones GP, Pratchett MS, Devitsina GV, Doving KB (2009b) Ocean acidification impairs olfactory discrimination and homing ability of a marine fish. Proc Natl Acad Sci USA 106:1848-1852

Munday PL, Hernaman V, Dixson DL, Thorrold SR (2011) Effect of ocean acidification on otolith development in 
larvae of a tropical marine fish. Biogeosciences 8: 1631-1641

Munday PL, Watson SA, Parsons DM, King A and others (2016) Effects of elevated $\mathrm{CO}_{2}$ on early life history development of the yellowtail kingfish, Seriola lalandi, a large pelagic fish. ICES J Mar Sci 73:641-649

Nilsson GE, Dixson DL, Domenici P, McCormick MI, Sorensen C, Watson SA, Munday PL (2012) Near-future carbon dioxide levels alter fish behavior by interfering with neurotransmitter function. Nat Clim Change 2: 201-204

Pannella G (1971) Fish otoliths: daily growth layers and periodical patterns. Science 173:1124-1127

Pastor AM, de la Cruz RR, Baker R (1992) Characterization and adaptive modification of the goldfish vestibuloocular reflex by sinusoidal and velocity step vestibular stimulation. J Neurophysiol 68:2003-2015

Paxton JR (2000) Fish otoliths: do sizes correlate with taxonomic group, habitat, and/or luminescence? Philos Trans R Soc Lond B 355:1299-1303

Platt C (1983) The peripheral vestibular system of fishes. In: Northcutt RG, Davis RE (eds) Fish neurobiology, Vol 1. University of Michigan Press, Ann Arbor, MI, p 89-123

Popper AN, Ramcharitar J, Campana SE (2005) Why otoliths? Insights from inner ear physiology and fisheries biology. Mar Freshw Res 56:497-504

Réveillac E, Lacoue-Labarthe T, Oberhänsli F, Teyssié JL, Jeffree R, Gattuso JP, Martin S (2015) Ocean acidification reshapes the otolith-body allometry of growth in

Editorial responsibility: Stylianos Somarakis, Heraklion, Greece juvenile seabream. J Exp Mar Biol Ecol 463:87-94

> Riley BB, Moorman SJ (2000) Development of utricular otoliths, but not saccular otoliths, is necessary for vestibular function and survival in zebrafish. J Neurobiol 43: 329-337

Rombough PJ (1988) Respiratory gas exchange, aerobic metabolism, and effects of hypoxia during early life. In: Hoar WS, Randall DJ (eds) Fish physiology: the physiology of developing fish eggs and larvae. Academic Press, San Diego, CA, p 59-161

Simpson SD, Munday PL, Wittenrich ML, Manassa R, Dixson DL, Gagliano M, Yan HY (2011) Ocean acidification erodes crucial auditory behaviour in a marine fish. Biol Lett 7:917-920

Spencer RF, Baker R (1992) GABA and glycine as inhibitory neurotransmitters in the vestibuloocular reflex. Ann N Y Acad Sci 656:602-611

Straka H, Dieringer N (2004) Basic organization principles of the VOR: lessons from frogs. Prog Neurobiol 73:259-309

> Szentagothai J (1950) The elementary vestibulo-ocular reflex arc. J Neurophysiol 13:395-407

> Tseng YC, Hu MY, Stumpp M, Lin LY, Melzner F, Hwang PP (2013) $\mathrm{CO}_{2}$-driven seawater acidification differentially affects development and molecular plasticity along life history of fish (Oryzias latipes). Comp Biochem Physiol A 165:119-130

Wallman J, Velez J, Weinstein B, Green AE (1982) Avian vestibuloocular reflex: adaptive plasticity and developmental changes. J Neurophysiol 48:952-967

Submitted: November 24, 2015; Accepted: June 4, 2016 Proofs received from author(s): June 28, 2016 